\title{
SOCIAL PORTRAIT OF WOMAN IN THE CONTEMPORARY MASS CINEMA
}

\author{
Natalia Babenko ${ }^{1}$, Uliana Yatsyshyn ${ }^{2}$ \\ Lviv Polytechnic National University, Lviv, Ukraine \\ ${ }^{1}$ Student of bachelor's program "Sociology", Department of Sociology and Social Work \\ ${ }^{2}$ Ph.D., Associate Professor, Department of Sociology and Social Work
}

Background: the movies are truly an art of our time. It is the greatest aesthetic and educational force in the world today. Everyone can get information that interests him only, no matter what the meaning is in the film. Most likely the person finds answers to his questions in a particular film. Such films very often become an incentive for any action and inspire a person to act.

Purpose: to establish changes in the social portrait of woman in the contemporary mass cinema in the past times (twenty-thirty years ago) and today.

Methods: we used the theoretical analysis of information, review and analysis of serials and movies of the past and present times.

Results: theoretical and empirical analysis shows that the social portrait of woman in the contemporary mass cinema had been changing a lot from old time till nowadays. Also, we think that it is going to change.

Conclusion: Comparing the social portrait of woman in the mass cinema of the past (twenty-thirty years ago) and in modern times, it can be noted that it has undergone dramatic changes.

Keywords: serial, cinema, woman, social portrait.

На початку людської історії існували різні інститути, які своїм функціонуванням встановлювали норми та цінності у суспільстві. Це, наприклад, релігія, сім'я, література, мистецтво. Сьогодні величезний вплив на суспільство має мас-медіа, в тому числі кіно як його складова частина. Кіно не можна віднести до однієї конкретної сфери суспільного життя, воно входить до складу різних її сфер: культурної, соціальної, економічної та ін. Кіно є не тільки твором мистецтва, але i частиною медіакультурного простору, виступаючи в якості комунікативної системи. Кіно є потужним регулятором суспільних відносин, що робить його соціальним інститутом, вартим ретельного дослідження.

Кіно як наймолодший вид мистецтва, має нерозривні зв'язки з багатовіковою художньою культурою, успадковує і транслює досвід і традиції літератури, історії, релігії. Розвиток і збагачення можливостей кіно дозволяє даному виду мистецтва гостро і живо впливати на свідомість глядача, формуючи певні образи, ідеали, уявлення. Відповідно, кіно має найбагатший набір засобів і інструментів, необхідних для трансляції будь-якої ідеї. (Баженова Л. et al., 2008)

Тому в соціології й виокремився окремий напрям, який присвячений кіно. Соціологія кіно займається вивченням різноманітних проблем, пов'язаних з функціонуванням в суспільстві фільму та кінематографу в цілому. Вона досліджує глядацьку аудиторію в іii складі, різноманітності, еволюції, встановлює закономірності кіносприйняття, особливості формування глядацьких потреб, очікувань, системи культурологічних цінностей. Соціологія кіно вивчає прямі та зворотні зв'язки кіномистецтва 3 його надзвичайно складною, динамічною аудиторією і тим самим взаємодіє з історією та теорією кіно. Дослідженню кіно 3 соціологічної перспективи присвячені праці: Т.Адорно, Е.Алтенло, А.Базен, А.Бергесен, В.Беньямін, П.Бурдьє, 3.Кракауер, Ю.Лотман, Дж.Маєр, М.Маклюен, Е.Морен, М.Моріс, Дж.Орр, К.Прендергаст, А.Тудор, Т.Хейз, М.Янкович та інші. Серед сучасних українських дослідників сучасної ситуації взаємовпливу кіно і суспільства є Д.Виставкіна, О.Коновалов, Н.Костенко, Ю.Сорока, Р.Шульга та інші.

Кіно виникло в 1895 році, коли брати Люмьєр вперше провели кіносеанс. Сьогодні кіно $є$ потужною індустрією, в якій задіяні мільйони людей, до його створення залучають найновітніші технології. Не дивно, що воно впливає на інші сфери культури (телебачення, кінотеатри, театри, технології тощо). Воно динамічно розвивається, реагуючи на запити 
вибагливої аудиторії. Зокрема, сьогодні активно розвивається ринок виробництва серіалів, зростає їхня естетична і технологічна якість. Проте якщо проблемі кіновиробництва та кіноспоживання соціологи приділяють увагу, то серіали поки що залишаються поза їхнью увагою.

Вплив кіно на людину важко переоцінити. Кінофільм захоплює емоції людини, їй нав'язуються уявлення, які за глибиною переживання можна зарахувати до її власного досвіду. Кінематограф - це великий винахід, який справив величезний вплив на формування світогляду людини XX століття. Кіно - найбільш «передовий» вид мистецтва, де використовують багато наукових відкриттів. За широтою охоплення дійсності і глибиною проникнення в неї, за силою впливу на глядача через зір і через слух воно перевершило інші мистецтва. Кінообраз розширив як сферу художнього освоєння життя, так і сферу нашого естетичного переживання. На екрані важко видавати себе не за того, хто ти є. Але чи означає це, що перед нами правдиве мистецтво, що можливості реалістичного відображення життя безпосередньо закладені в його природі і що саме тут, завдяки високим досягненням сучасної техніки, мистецтво переступає ту умовну і разом з тим об'єктивно існуючу грань, яка відділяє його від життя (грань, яка $\mathrm{i}$ сьогодні залишається обов'язковою для всіх інших мистецтв), і діє у сфері безумовного, безпосередньо оперуючи формами самого життя.

Німецький соціолог Вальтер Беньямін у 1930-і роки написав про те, що кіно є найбільш розвинутим імперіалістичним засобом контролю над масами. Давно вімічено, що кіно впливає на поведінку людей: підсвідомо людина намагається діяти відповідно до свого улюлбленого героя. Найбільше піддаються цьому діти, але й дорослі не позбавлені інстинкту наслідування (Денисенко О., 2012). Відтак, великий інтерес викликає проблема формування у глядачів певних світоглядних установок і посилів, які транслюються через кіно та серіали до глядачів.

На межі XX-XXI ст. світ переживає грандіозні зміни у багатьох сферах життєдіяльності, масштабну трансформацію традиційних ціннісних систем та етичних ідеалів. Процеси глобалізації і формування медіа-культури, характерні для сучасної цивілізації, визначили становлення нового постіндустріального типу суспільства, якому притаманне впровадження інформаційних і комунікативних технологій в усі сфери громадського життя і, відповідно, зміна ціннісних пріоритетів та світоглядних основ людини. Трансформація, що відбулася, вплинула на гендерні уявлення та взаємини чоловіків і жінок, а також у цілому на стан інституту сім'ї. Зовсім нового змісту набувають уявлення про жіночність і жінку, iї роль i становище в сучасному суспільстві. У медіа-просторі все очевидніше й масштабніше помітна трансформація традиційного образу жінки.

В українському суспільстві жінка завжди виконувала роль хоронительки традиційної культури і цінностей. Образу жінки, більшою мірою жінки-матері, в суспільній свідомості належало особливе місце, він вплинув на формування системи цінностей, притаманної українському суспільству, а також відіграв важливу роль у процесі формування української національної самосвідомості. Однак нині активність інформаційних процесів у суспільстві настільки висока, що підпорядковує собі традиційні елементи і цінності високої культури, які значно трансформуються під впливом і повсюдним поширенням масової культури (Ковальова \& Даніл'ян, 2011).

У процесі глобальної трансформації гендерні ролі українців значно змінилися, породивши цілий комплекс серйозних суперечностей, змішавши традиційні гендерні уявлення 3 новими i викликавши хвилю неоднозначних оцінок. Під впливом медійних технологій, в тому числі і зарубіжного кіно, образ жінки трансформується в українській культурі та житті, що природно актуалізує проблему їі ідентифікації в сучасному суспільстві (Ковальова \& Даніл'ян, 2011).

Образ жінки в серіалах зазнав кардинальних змін протягом останніх двадцяти-тридцяти років. У багатьох серіалах нарешті почали з'являтися різні образи та характери - сатиричні, амбіційні, рішучі жінки, які не гірше, а іноді навіть краще за чоловіків справляються з будьяким завданням. I ця тенденція прогресує з кожним роком.

Найкраще еволюцію можна простежити на прикладі серіалів, які транслюються протягом декількох років. Яскравим прикладом зміни образу жінки у кіно/серіалі є франшиза “Зоряний 
шлях". Перші епізоди вийшли в світ в 1966 році. Жінки у серіалі були представлені в образі членів екіпажу, але основною функцією їх було приносити чоловікам їжу. Сдиною жінко. На містку була чорношкіра радистка Ухура, яка була активно задіяна у декількох епізодах. Проте звертає на себе увагу те, що жінки на екрані були одягнені у максимально коротенькі спідниці, що підкреслювало їхню сексуальність. У подальші роки було випущено низку серіалів та повнометражних фільмів всесвіту “Зоряного шляшу”. Останній серіал цієї серії є “Зоряний шлях. Пікар" (2019 рік), де центр уваги чітко переміщений до емансипованих жінок: сестрисинтетики Даж і Соджі, доктор Агнес Джураті, колишня офіце Зоряного флоту Раффі, борг Сьома з дев'яти та антагоніст Нарісса. Ці жінки рішучі, їхні характери прописані, їхня роль у сюжеті важлива. Навіть зовнішній вигляд позбавлений об”єктивації, притаманної першим снріям і фільмам кіновссвіту.

Вражає також як з часом змінювався акцент в тих рисах, які цікавили самих глядачок. У 1998 році вийшов серіал “Секс і місто” (1998-2004), в центрі сюету якого були чотири самодостатні активні жінки, які намагаються налагодити своє життя в Нью Йорку (часто чоловіки відігравали в цьому вирішальну роль). Молоді гетеросексуальні жінки часто асоціювали себе 3 його героїнями. Але сьогодні глядачки надають перевагу Дайнеріс із «Гри престолів» (2011-2019) - сильна, розумна жінка-воїн, майбутня королева, мати драконів; Темперенс Бреннан 3 «Кістки» (2005-2017) - антрополог, автор детективних романів, має три докторських ступені, володіє кількома видами бойових мистецтв, займається полюванням та дайвінгом. Вперше за всю історію роль Доктора в серіалі “Доктор Хто” (1963 до тепер) виконала жінка. Нестандартно сильні жіночі образи в серіалах стали тенденцією сучасності (“Чому жінки вбивають", "Гострі предмети", "Батьківщина", "Убиваючи Єву" тощо). На нашу думку, прикладом образу сильної жінки є серіал «Велика маленька брехня» (2017-2019) — американський драматичний телесеріал каналу $\mathrm{HBO}, \quad$ головними героїнями є п'ять жінок, яких об'єднує страшна таємниця-вбивство чоловіка, з кримінальним минулим насильницького характеру, однієї з героїнь, який постійно знущався над дружиною. Жінки згуртовуються, щоб захистити подругу та самих себе, і в них все закінчується добре, вбивство офіційно вважається нещасним випадком.

Сильні й незалежні жінки, які менше уваги приділяють стосункам та домогосподарству, головними сюжетними лініями яких не є догляд за дітьми, покупки в інтернет-магазинах, піклування про чоловіка - головні героїні серіалів та кіно сьогодення.

3 часом змінюється не тільки типаж образу жінки у кіноіндустрії, але й ії характер та риси зовнішності. Тепер сильній жінці зовсім не обов'язково носити тільки «чоловічий одяг», зовсім не фарбуватися і надавати перевагу кросівкам замість підборів. Друга хвиля фемінізму з 1970-х років критикувала культурну увагу до різниці між чоловічим і жіночим тілом та боролася за можливість не голити волосся на тілі, не користуватися косметикою i сексуалізованим одягом, адже все це патріархатні вимоги, нав'язані жіноцтву. Однак з кінця 1990-х традиційні прояви фемінності, як-от помада для губ, високі підбори або гламур, більше не конфліктують 3 жіночою силою і незалежністю.

За останні тридцять років автори серіалів та кіно нарешті відійшли від образу ідеальної, наївної жінки-домогосподарки, в житті якої існує тільки сім'я та домашні обов'язки, нам показують справжніш жінок. Вони старі й молоді, не тільки 90-60-90, темношкірі, азіатки, на різних керівних посадах. У серіалах останніх років до образу жінки почали ставитися серйозніше. Ці образи перестали бути пласкими - з'являється бекграунд особистого досвіду, стосунків з іншими героями, проблем і перемог. Немає єдиного образу - жінка еволюціонує 3 кожним новим серіалом чи фільмом, іiі життя дуже різноманітне, перед нею відкриваються нові можливості. І це стосується не тільки жіночих образів. Ще декілька років тому тему ЛГБТ спільнот у серіалах було майже табуйовано, нині ж вони є майже у кожному, прикладом може слугувати дуже популярний сьогодні серіал компанії «NETFLIX» «Статеве дозрівання» (2019), там ця тема підіймається і обговорюється дуже детально, ій присвячено багато епізодів. Персонажі змінюються, стають реальнішими, і нам простіше ототожнювати світ кіноіндустрії iз нашим. В інших серіалах серед головних персонажів $є$ жінки-представниці ЛГБТ або 
бісексуалки (“Фостери”, “Помаранчевий - хіт сезону”, “Сотня”, “Бетвумен”, “Зачаровані” та багато інших).

Отже, серіали займають велику частку телевізійного і інтернет контенту. Вони завойовують популярність якісним виконанням, гарною грою акторів, нетривіальними сюжетами. Вони бувають фентезійними або розповідати про реальність, але у них завжди відображені люди, їхня поведінка, рішення, переживання. Хоча люди дивляться серіали зазвичай для відпочинку й розваги, глядачі співпереживають персонажам, часом наслідують їхні вчинки і погляди на життя. Відтак, з одного боку, кіно/серіали є віддзеркаленням життя, а з іншого - його конструктором.

\section{Список використаних джерел}

Баженова, Л., Некрасова, Л., Курчан, Н. \& Рубинштейн, И. (2008). Мировая удожественная культура. ХХ век. Кино, театр, музыка, 432.

Денисенко, O. (2012) Що може кіно. Кіно театр, (3). URL: https://ktm.ukma.edu.ua/show_content.php?id=1351

Ковальова, Г. П., \& Даніл'ян, В. О. (2011). Трансформація жіночої гендерної ідентичності в сучасному медіа-просторі. Вісник Національної юридичної академї Украӥни імені Ярослава Мудрого, (11), 148-157.

Signorelli, T. \& Tudor, A. (2016) For a sociology of the cinema. The SAGE Handbook of Cultural Sociology, 481-495.

\section{References}

Bazhenova, L., Nekrasova, L., Kurchan, N. \& Rubinshteyn, I. (2008). World art culture. XX century. Cinema, theater, music, 432.

Denysenko, O. (2012) What cinema can do. Cinema Theater, (3). URL: https://ktm.ukma.edu.ua/show_content.php?id=1351

Koval'ova, H. P., \& Danil"yan, V. O. (2011). Transformation of women's gender identity in the contemporary media space. Bulletin of the Yaroslava Mudroho National Law Academy of Ukraine, (11), 148-157.

Signorelli, T. \& Tudor, A. (2016) For a sociology of the cinema. The SAGE Handbook of Cultural Sociology, 481-495.

\section{Contact information:}

Babenko Nataliia nataliia.babenko.so.2016@1pnu.ua

Yatsyshyn Uliana

Uliana.V.Yatsyshyn@1pnu.ua 